\title{
Jan Kłos
}

\section{The State - a necessity or an enemy?}

\begin{abstract}
This paper seeks to show the State in its historical and analytical approaches. In view of history, we find two principal solutions. In this text they are called metaphysical and contractual. The metaphysical solution is characteristic of the pre-modern era with its Aristotelian claim that we carry the social principle in our human nature; the principle is the spawning ground for the State. Now, the contractual, i.e. the modern, approach defines the State as a result of human negotiation. Historically speaking, there have been many proposals along the spectrum from an overgrown institution to its, much atrophied, form. The author proposes a modest approach to our understanding of the State: it is needed from the well-being of social community. The condition, however, of this well-being is that the State be limited, allowing much space for its society to grow and form indispensable interrelations.
\end{abstract}

Keywords: history, Hobbes, Locke, limitation, Ludwig von Mises, Nock, Poland, Spencer, State.

Lex facit legem ${ }^{1}$

There are many definitions of the State. Aristotle understood it as a perfection of the social principle inherent in human nature, whereas St. Augustine saw in the State a remedy against human depravity, therefore its main purpose was to curb human evil drives. The State performs a negative function: to prohibit antisocial behaviour. Sinless and perfect human beings would not need any State. St. Thomas Aquinas, for his part, followed the Aristotelian model, i.e. the State understood as a perfection and institutional form of the social principle. The moderns came up with their own definitions. In their view, the State is the result of a social contract, the establishment of the State is negotiable.

Apart from these, say, positive views as to the practicability of the State, history up to now has witnessed numerous attempts to undermine its rationale. Such attempts are not new, for they had already appeared in antiquity among the group of the naturalistically-minded Sophists. They set the model of private lifestyles in opposition to the publically approved rules. As we know, many contemporary

\footnotetext{
${ }^{1}$ This phrase was well known both in Poland and in England. It held that the king was bound by the law.
} 
schools of democracy, liberalism or anarchy are founded in antiquity. Nowadays liberal democracy appears to be the most universally advocated political regime. In the western countries it seems to be the only rational form of political institutions.

Some claim, for instance, that democratic states are more prone for peace than others (Rummel 1997: 25-49). Can we accept this conclusion without any reservations? Most probably not, taking into consideration quite recent cases of journalists censored whenever their reports on some current events are contrary to the authorities' expectations, or else they fail to satisfy the requirements of political correctness. (An almost classical example for me is the way journalists cover any conflicts with immigrants from African countries. If the comments go against the official line of propaganda, they are rejected and their authors are ostracised. Some western politicians harbour a grudge against those from Eastern Europe who oppose uncontrolled immigration)2. All such measures obviously contradict freedom of speech, which is the bloodstream of democracy, and, at least theoretically, the most cherished value in otherwise democratic countries. Naturally, we have to admit that, potentially, democracy provides certain conditions for peaceful coexistence, but just like any other political system is not immune from corruption.

Presently we may often feel at a loss. We are living in a globalizing world, so we have a very vague sense of state borders, a feeling common especially in the EU countries. Now contemporary States often embark on multicultural policies. Such policies in turn take on a very cosmopolitan form. This comes eventually to rejecting the foundations on which human identity can be established. Who am I if this State, immersed in the maelstrom of globalizing and multicultural influences, abandons its concrete cultural shape? If the State is an outcome of a long historical process, as I claim it is, what happens to the State that denies its identity? Can human identity develop if it is not buttressed by strong identity-making constructions of the State, i.e. socio-cultural institutions?

The above questions are important in any serious discussions about the State. This text seeks to show in brief its basic foundations in their historical outline. Part I focuses on the rise of the modern State, part II claims that for a proper development of society the State must be limited, and part III discusses some elements of Polish history.

${ }^{2}$ See I. Krastev, 2017, After Europe, p. 45. For instance, Krastev's book criticizes the conservatives from Hungary or Poland. He rightly observes that the citizens from Central Europe "for the most of the twentieth century $[\ldots]$ were preoccupied either with emigrating or with taking care of immigrants" (p. 46), but at the same time he fails to notice these immigrations were basically within the same culture and presented no danger with which we are confronted at the moment. 


\section{The rise of the modern State}

The moderns began to consider the essence of the State and its claims when they realized that they could renegotiate its many functions which had up to then been taken for granted. Philosophically speaking, modernity can be defined as a daring project to look a new not only at the scientific but also political picture of the world. As a result, modernity dared to undermine numerous time-honoured institutions. It began to doubt the claims to unconditional obedience to the State, stressed the importance of the individual and social communities to which the individual belongs. An important question arose: is the individual subservient to the State or the State should be subservient to the individual?

As we look at the history of the State, we find two basic sources of its conception: let us call them natural (or: metaphysical) and contractual. The natural source goes back to ancient philosophy, in particular to Aristotle, where we find human nature being a composite of individual and social elements. Thus the State is anchored in human social nature. The structure of the State is therefore not superimposed on otherwise purely individual human beings. It is rather the other way round: the State is a natural development of social character, it is the perfection of social elements inherent in human beings.

Now the contractual vision of the State views the human being as primarily individual and it is for the sake of his individualism that it is invented or, to be precise, negotiated. If the State is not rooted in human nature, there must be some good reasons for inventing it. In relation to various contracts, just as in trading, the State is tailored to human needs. Thomas Hobbes, for that matter, envisioned it as a safeguard against the vulnerable and frail human life. First he defined the hypothetical pre-political State as a very precarious and inauspicious time for human beings in which they may easily lose their lives, for it is the time of blind power. Those who are more powerful prevail. There is no justice and no court of appeal to which the needy can turn; they risk their lives unless they create a State - their Leviathan that will define justice and create an arbitration court. For Hobbes, unlike for Aristotle, the individual is naturally anti-social. The position Hobbes held was already anticipated by the naturalist ancient philosophers.

For John Locke, the pre-political state was not that pessimistic as in Hobbes because the human beings are providentially endowed by God with certain natural goods, the bona civilia, including life, liberty, and the right to private property. Henceforth human beings do not have to attend on the State (the contractual entity) to define their communal life. The State's end is much more modest - it is supposed to protect what has otherwise being granted by the Supernatural Being.

Yet another conception of the pre-political state is found in Jean Jacques Rousseau. In his conception, the human being is naturally good but surrounded by artificial conventions. This vision is clearly revolutionary, for the good human 
being feels entitled (or even encouraged) to do away with the artificial framework, to decompose it in order to help the free and good human creature live according to his own purposes. The revolution should extricate him from hostile environment.

Despite the fact that at the moment many supranational organizations exist, the nation-States are still present. Modern States were born under very violent circumstances in Europe. Let us mention some of them: the Thirty Years' War (1618-1648). This war had brought the fragile medieval order to an end, a fact that completed the processes initiated by the Reformation. It was waged on a very delicate ground of religious differences and shocked European inhabitants with its cruelty. Therefore the idea of toleration was born in the European minds. Politically speaking it was the Peace of Westphalia (1648) that marked the end of atrocities. Henceforth the state as a sovereign entity came to existence.

Europe came to be dominated by nation-States, and it is at that time that "processes were set in motion that led Europe to dominate the world" (Ray 1990: 188). Not only were European nation-states (Spain, Portugal, Great Britain, and the Netherlands) politically dominant on the global stage, but they also became dominant in the area of economics. The Renaissance ushered in the spirit of exploration and exploitation that began an unprecedented period of European robustness. The Europeans spread civilization all over the world, at least they regarded themselves as such. The American political scientist, James Lee Ray, claims that exploitation boosted global development and although it created many problems, "people who remained isolated from that system did not live in a pristine paradise, either" (Ray 1990: 189).

The eighteenth century was dominated by dynasty conflicts and "a series of balance-of-power wars, with the British and the French being the major opponents" (Ray 1990: 190). It was also cosmopolitan in action. Various countries employed diplomats from other countries, and nationalities intermingled. Royal families intermarried, for they hoped to limit conflicts. Ray observes: "In the eighteenth century, states were cross-pressured in the sense that their antagonism toward each other was softened by the possibility of relatives being in the service of opponents" (Ray 1990: 190). One of the most spectacular conflicts then is the War of the Spanish Succession (1702-1713). Royal families, e.g. the French Bourbons, the Hapsburgs and the English, were very often rivals to domination. Then, towards the end of the eighteenth century, yet another player was gradually stepping onto the global stage, namely the United States of America. Interestingly enough, this player, although at the moment of its inception ridiculed or ignored, would ultimately dominate the stage. It was difficult to retain the balance-of-power principle, therefore this is perhaps why the appearance of a new political body over the Atlantic Ocean was initially treated with mistrust and discontent. Europeans did not believe in the permanent existence of a republic. And here again we find some evidence for the fact that inasmuch as the fragile European order resulted 
from short-lived periods of amity in the balance of power, the American order was founded on the modern philosophical ideas. America had not rivals of some political significance to negotiate with, therefore despite the climatic difficulties and the hostility of the aborigines, it was relatively easier to set in motion a series of action. Let us take for example the famous Louisiana Purchase (1803). The owners of Louisiana were far away and involved in conflicts. Louisiana originally belonged to the French and then it was sold to the Spanish. When the idea of retrocession arose in the French minds, for they also cherished the idea of a New France, the Americans stepped in with an offer of a large sum of money. Napoleon desperately needed some recompense for his battles in Europe, so he eventually complied. Sadly enough, Poland in the eighteenth century had ceased to exist; she was partitioned between Prussia, Austria, and Russia.

The French Revolution that erupted towards the end of the eighteenth century is often defined as the climax of modern philosophy in its attempts to liberate the individual and to place him amidst some universal and negotiable context of the legal framework. Inspired by modern philosophy, in its enlightened version, people attempted to recompose the world, placing in its centre the knowing ego (Cartesian ego cogito). Initially, the aims of the revolution were modest, simply "liberty, equality, and brotherhood for the French people" (Ray 1990: 190), but then the revolution turned expansionistic ${ }^{3}$. This expansionism, as a way of self-defence reaction on the part of France's enemies, triggered nationalism amongst them. As a consequence of the Napoleonic wars, the spirit of national liberation was born: the Greeks, the Hungarians, the Poles, and the Italians fought for national liberation (to mention just a few examples in Europe, but there were other countries as well that yearned for it). Despite the negative side effects of colonization, Europe was generally looked up and, as Ray states, apart from the critics others "have adhered enthusiastically to the European concept of nationalism and have clearly desired to imitate Europe by developing modern states" (Ray 1990: 194).

In fact we are presently dealing with various modifications of the above models, which mix certain elements. At the moment, at least officially, the inhabitants of the West vacillate between a limited power of the State and demands for an enlarged welfare system. In this dynamic liaison between the State and society, the latter is always trying to retain some space of independence, but at the same time expecting from the State to introduce safety measures. Surprisingly, the contradictory character of such demands is ignored. Let us look briefly at some examples of unlimited power ${ }^{4}$. No matter who holds the power: a king, a president, or a parliament, it must be checked.

${ }^{3}$ It is interesting to observe that America, for that matter, sought to retain her neutrality rights. In the nineteenth century she was dominated by ideas of expansionism.

${ }^{4}$ See the negative examples of unlimited power in: R.J. Rummel, 1997, Power Kills. Democracy as a Method of Nonviolence, passim. 


\section{The State must be limited or eliminated}

In his well-known classic, Herbert Spencer calls the divine right of kings "the great political superstition", and he rightly observes that this superstition still holds because it is transferred on "the divine rights of parliaments". Spencer writes: "The oil of anointing seems unawares to have dipped from the head of the one on to the heads of the many, and given sacredness to them also and to their decrees" (Spencer 1982: 123). The British philosophers ridicule this new attitude, rightly observing that inasmuch as the divine right of kings was incorrect at least it was more consistent than the present reverence for parliaments. Bestowing divine rights upon kings (or any individuals) is just as improper and indicative of idolatry as the naïve belief in the voice of the popular infallible opinion residing in parliaments. Spencer therefore claims that no one has the right to unlimited power or unconditional obedience because no one is in possession of absolute truth. As regards parliaments, the situation in Europe is even more complicated because apart from State parliaments we have the supranational parliament that claims our obedience.

The American Founding Fathers knew well about it, so they included the mechanism of the division of powers and checks and balances in the governmental structure. The State cannot become a machine empowered with uncurbed possibilities. Rather, it should be inherently divided into a multitude of interests which compete with one another.

Modernity had brought many liberal overtones into the thinking about the State. Kalyvas and Katznelson claim that liberalism is a natural consequence of republicanism. Republicanism was a mediate structure between monarchy and liberalism, especially in the period between 1750 and 1830, when "antimonarchical discourse was predominantly republican" (Kalyvas, Katznelson 2008: 4). The issues under consideration focused on how to combine "virtue and self-interest, the common and the personal, sovereignty and representation, authority and freedom, law and ethics" (Kalyvas, Katznelson 2008: 3). All these elements in fact make up the main fabric of any State, therefore we can treat them as an enlarged context of what the State should consist in. No doubt virtuous society is important and may even be treated as a prerequisite for a proper functioning of the State, but modernity argues that it is not the State's role to make people virtuous. In the medieval past the Church was an important moderating factor, but under the circumstances of divided Christianity, plurality of religions, and an array of multicultural ideas religion has ceased to provide a consistent message on what should be done. The situation has become very complicated but not hopeless. We can still rely on the testimonies of concrete people. Witnessing as important though it be, it is not enough, neither does it have to be. When reflecting on the State and on its principal structures, we can still claim that no matter how varied its social elements may be there are certain ingredients without which no State can exist. 
If we take the United States of America, for instance, we find there the underpinning elements of Lockean bona civilia: life, liberty, and private property translated in the American context into life, liberty, and the pursuit of happiness. This is the philosophical heritage, aside to many others. Now the theological element is the perception that God created all people equal - such was the underlying principle of the Declaration of Independence. Theoretically speaking, these elements are clear, so that common sense may readily accept them. In practice, however, we know how tedious was the process of understanding and implementing the basic truth that people are equal because God made them equal. The interesting thing is that once this truth is undermined, the philosophical part is refuted as well. If black communities are not treated as consisting of equal human beings, neither are treated their life and liberty (let alone the pursuit of happiness) as deserving the like respect.

The founder of the Austrian School of Economics, Ludwig von Mises, is a realist in his approach to the existence of government. In his Human Action we read that "[a government] always furthers the interests of some groups of people at the expense of other groups. It never serves what is called the commonweal of the public welfare" (Mises 1966: 422). He is well aware that human beings are not ideal creatures. Their plans must often be enforced, if they wish to peacefully carry them out. Society is a complex structure of a variety of interrelations. Governments counteract any attempts at the decomposition of asocial forces. Mises certainly realizes that social peace is a necessary condition for the implementation of plans. Therefore there must be provision "for violent prevention and suppression of antisocial action on the part of refractory individuals and groups of individuals" (Mises 1966: 719). Individuals are not ideal creatures, hence violence on the part of the State is not wrong in itself because individuals are often violent and chaotic. The legal order, if it is to mean anything, must carry along enforcement. The individuals understood as rational creatures, that is, capable of recognizing the law, should also be aware that they could be punished for its violation. Government is not an evil in itself, for such a description would boil down to a value judgment. Rather, one should adopt a pragmatic approach, i.e. the State is a means to an end. The State should neither be deified nor denigrated, unless we understand human beings differently than they really are. It follows from this that if we want to realize our plans, we need to be subjected to certain limitations.

Mises lays out this pragmatic order when he writes: "The sphere in which coercion and compulsion is applied and the content of the laws which are to be enforced by the police apparatus are conditioned by the social order adopted. As State and government are designed to make this social system operate safely, the delimitation of governmental functions must be adjusted to its requirements. The only standard for the appreciation of the laws and the methods for their 
enforcement is whether or not they are efficient in safeguarding the social order which it is desired to preserve" (Mises 1966: 720).

Contrary to libertarian approach, especially that of anarchocapitalists, Mises does not consider the State as such, an ideal being distilled from its context, a hypostasis of Reason. The State for him is related to the overall social structure and the ends it seeks to attain. In Aristotle, the State results from human social nature; in Mises, it is accrued to utilitarian principle. Aristotle elicits the ingredients of social life from human social nature; Mises refers them to the social system that has been established. Therefore there is no justice as such, there is justice in relation to the system, i.e. related to expediency and welfare. Mises explains: "It is not justice that determines the decision in favour of a definite social system. It is, on the contrary, the social system which determines what should be deemed right and what wrong" (Mises 1966: 721). Here we have what I would call a Platonic approach rather than Aristotelian, or deduction rather than induction. In other words, we deduce justice from our social organization, i.e. first we have the ideal superstructure from which we can define its practical implementation. We cannot understand what is right or wrong outside the social system. Shall we then justify any system as long as it is coherent if we cannot evaluate its elements? There is no metalanguage by which we could evaluate individual elements of a given system. It is therefore futile to criticize for instance intervention as such. We can criticize it, however, in relation to its being useful for social cooperation.

The nineteenth-century political writer, Frédéric Bastiat, provides us with a very important lesson as to our understanding of the State. First of all, we need to make a distinction between what the State is and what our expectations with regard to the State are. Besides, it follows from this distinction that quite frequently we cherish contradictory sentiments. For instance, we want to have our State limited, with a low level of taxes, and at the same time we expect it to lavish benefits on its citizens. One should make a decision: either a modest State or a generous one. We cannot have both. A modest State does not need much money, its bureaucratic staff is reduced, for it does not aspire to solve all the problems; a generous State gives a very misleading sense of sympathy and safety. Is citizens believe that they live under the shelter of a very benevolent government. They fail to notice that their State relies entirely on the money it receives in the form of taxes.

Obviously, some people may argue whether the State needs an identity. I think that in the long run a State without any identity cannot last longer, cannot withstand all the external forces that push it. We should avoid that maelstrom of narrow nationalism, but to cherish patriotic feelings is not coequal to hostile nationalism. As it was once excellently formulated by Agnes Heller, the Jewish Hungarian philosopher, fundamentalism is there where there are no foundations. It follows from this statement that foundations can or even should exist with running the risk of turning into fundamentalism. 
In my opinion, all these critical remarks intended to undermine the very existence of the State usually result from two reasons: 1) the State ignores society, 2) the State is used (or, rather, abused) by some groups in order to oppress other groups. If the State, for instance, accrues to itself too much power, different groups compete to politically appropriate it in order to use it for their own benefit. Then a certain phenomenon takes place that is called by Nock "the conversion of social power into State power" (Nock 1989: 11). Talking about States one cannot omit the question of the relationship between power and authority. Are they synonymous or entirely different? Those who hold power do they possess thereby authority? Ray clearly defines it as a "distinction between what a state possesses and what a state is able to do" (Ray 1990: 194). We may say that if a State is very populous and occupies a large territory it is powerful, namely it has powerful resources, but does it at the same time have authority over the minds of its citizens? In other words, can this State dictate what its citizens should do, whether they can travel abroad, or what they are supposed to produce? The question is therefore about the limits of the State. How powerful should it be and what is the most effective manner in which the State's power can be exploited for the benefit of its citizens?

Nineteenth-century anarchists sought to annihilate the State. Karl Marx believed that the State would gradually cease to exist and be replaced by the international brotherhood of men, but the State was needed at the initial stage of the revolution that was to come.

The unrestricted power is naturally manifested by the ruler who usurps to rule his country with an iron fist, accepts no opposition, and crushes any criticism. In 1984, the Georgian film director Tengiz Abuladze produced a film entitled Repentance, a work that was immediately acclaimed as unprecedented and remarkable. Indeed this film deserves to be called a masterpiece, a genial portrayal of the depravity of totalitarian power. The film is full of symbolical, oneiric, realist and surrealist elements. It aspires to depict not a particular ruler, but to portray a dictator as such. It is a kind of cross section of totalitarian rulers no matter in which epoch they live, indeed a synthesis of a dictator, his epitome, be that Caligula, Hitler, Stalin or Pol Pot - all of them fit in the picture ${ }^{5}$. Therefore the actors are dressed in the uniforms of Roman soldiers, which means that the temporal dimension is not important and antiquity can be analysed just like the twentieth century. The audience must be prepared to these rapid shifts of attention and the historical perspective. Everything is immersed in symbolism. Even the name of the main hero is a meaningful symbol. It is Warlam Arawidze, a name which in Georgian means "the son of no one". Why is the totalitarian ruler "the son of no one?". I think that at least two reasons can be given for that:

${ }^{5}$ See an extensive analysis of the totalitarian State in: L. von Mises, 1985, Omnipotent Government. The Rise of the Total State and Total War, passim; also F. Oppenheimer, 1997, The State, trans. J. Gitterman, passim. 
1) first he does not need any relations, no external legitimacy for his power, indeed social relations only intrude. The ruler draws inspirations from the immanent world of his ideas rather than from the lives of real persons. He does not need any knowledge about society, what is more, in fact he does not need society at all, he is satisfied with an ideal vision, 2) the ruler does not need to create any social relations. They are even dangerous for the preservation of his power. They inspire opinions independent of, or contrary to, the authorities. Rather, the dictator creates interdependent relationships in which he is always the most important mediator. Society is under constant surveillance. Thus the dictatorial becomes an intimate of complete solitude, an immanent inhabitant of his self-proclaimed kingdom. Not only is there something unsocial in it, but even inhuman.

\section{The State and civil society - the case of Poland}

The question of limitation is linked with another question: to what extent, if at all, do we have to foster (and, consequently, value) the societal units in order to obtain a coherent whole? In our attempts to answer this question much depends on the goal of the one who keeps control. But what if there is no control because the structural elements of the State are not sovereign? They are subordinate to foreign institutions. How about the situation when there is too much control? Can we imagine the State as a self-controlled mechanism?

The American sociologist, Amitai Etzioni, writes about societal consciousness. Is the State necessary to preserve it? Poland is a good example that the State may not exist, yet society can retain its fundamental institutions even though it is subjected to enforced emigration. At the time of partitions society was dispersed in other countries. What is therefore retained in societal consciousness? The State does not exist, the invaders have taken over its institution, and yet members of the invaded nation retain something that decides about their identity as Poles. Lack of independence is a good evidence of the importance of meaningful symbols which define the ethos and culture. Etzioni calls them core institutions. In his book we read:

The development or construction of core institutions, limited primarily to the members of a cohesive societal unit, serves to symbolize the unit and to make it more visible to itself and to others, express its identity, and increase interaction among its members to the exclusion of non-members. A major way in which consciousness can be «concretized» is to associate it with a place and a related set of activities (Etzioni 1971: 231).

In order to retain national identity, when living in a foreign country, one must adhere to national values. How can we concretize consciousness in a foreign place? What kind of activities should be cultivated? Now the question is whether societal consciousness precedes collective action or else collective action precedes 
societal consciousness. If we consider the Polish uprisings of the nineteenth century, collective action was transformed into some violent expression of the yearning for sovereignty.

In the nineteenth century, at the time when Poland was partitioned and wiped out of the map of Europe, Polish conservative thought flourished - a fact that sounds contradictory. Conservatism is apparently associated with some efforts to preserve the status quo. There are in fact two tendencies at work here. Let us call them political and social (or societal). With regard to the political, it was naturally the time of revolutionary upheavals, therefore the time of liberating movements against the political status quo (we need to bear in mind that liberalism was born in the first half of the nineteenth century); within the social sphere, however, conservatism meant strong adherence to Polish history, language, religion, and institutions. Therefore the American historian of ideas, Rett Ludwikowski, rightly observes in his book "that the loss of independence need not undermine the foundations of society". And he enumerates: "the hierarchical structure of society, natural solidarity among social groups, the position of the family, religious foundations, and moral values were still intact" (Ludwikowski 1991: 2) ${ }^{6}$. Here the point of reference was the first in Europe (and the second in the modern world) written constitution (May 3, 1791). Now considering the Polish present and past the most important question is what should be preserved and continued and what should be discarded.

The tradition of Polish constitutionalism, i.e. the limitation of the king's power, goes back to the fifteenth century. At the time when other countries sought to reinforce absolutism, King Louis and King Jagiełło transformed Poland's hereditary monarchy into an elective kingdom. The king had to swear from then on to respect and protect fundamental governmental principles (free elections, the legislative power of Parliament, and the nobles' right to refuse obedience to the king if he violated these fundamental principles). The king's power was thus curtailed. Unfortunately, the nobles were given too much lee. They were free to break Parliament by one veto voice and too much concerned with their private affairs. We have to remember that similar processes were under work elsewhere. In Britain, the 1215 Great Charter brought habeas corpus act, but the liberating revolutionary processes in the seventeenth century were still not democratic. They were limited to the elite.

The danger of excess of power may come not only from the ruling authorities; it comes from any source of unrestrained power. The nobles in Polish history are a good example here. Ludwikowski observes: "None of the nobles of Western European countries were as successful as the Polish nobility at increasing their position and gaining greater power over the other estates" (Ludwikowski 1991: 8). Eventually: "By the end of the sixteenth century Poland, with its "democracy

${ }^{6}$ See more about Poland and her rise to democracy in: W.J. Rose, 1944, The Rise of Polish Democracy, passim. 
of the gentry» looked like an island surrounded by monarchies, which vested legislative, executive, and judicial power in one rule" (Ludwikowski 1991: 9). The principle of the king in Parliament was popular both in England and in Poland. The nobles firmly believed that the Parliament (Seym) was the real decision-making institution in the State. They sought to weaken the alliance between the king and the magnates, attempts that made rise to the concept of the liberum veto. The underlying principle was a complete equality among the nobles, and all laws should be passed unanimously. Thus an individual veto could dissolve the Seym or at times bring it to a standstill.

During the Saxon dynasty (1697-1763) this competition between magnates and gentry turned into an anarchy. They were concerned mainly with their private sinecures and vied for whatever vacant offices lavishly bestowed by the Crown and for life. The surrounding neighbours were vitally interested in fanning the flames of Poland's anarchy and "in keeping Poland demilitarized, neutralized, and in a state of anarchy. Since they were interested in maintaining the constitutional status $q u o$ in Poland, their propaganda argued that any change in the Commonwealth would be dangerous. Further, the anarchy in Poland was used to justify plans to partition off Polish territories" (Ludwikowski 1991: 13).

England, America, and the philosophers of the French Enlightenment were set up as paradigms for Polish democracy. The Constitution was proclaimed on May 3, 1791, and "despite [some] difference, the framers of both constitutions emphasized the significance of religious belief and incorporated this recognition into their constitutions" (Ludwikowski 1991: 27). Both constitutions referred to the will of the people as the founding principle of the laws enacted. The difference, however, resides in the fact that Poland approved of the Commonwealth of the Gentry.

Unfortunately, the Polish kings conceded too many rights on the Polish nobles, a fact that later on conspired against the kings and contributed to the loss of independence. They gained many privileges, therefore Ludwikowski notes: "None of the nobles of Western European countries were as successful as the Polish nobility at increasing their position and gaining greater power over the other estates" (Ludwikowski 1991: 8).

This requirement to limit power runs across the whole spectrum of Polish society. Ludwikowski even goes as far as to compare the relationship between the gentry and peasants in Poland to that of masters and slaves in America, for "the peasants were personally dependent on the gentry and subject to the jurisdiction of the gentry no less than the American slaves were subject to their masters" (Ludwikowski 1991:30). There are many similarities between the two constitutions. The Polish constitution sought above all to consolidate the nation, they advocated the separation of powers. As regards this separation, it was "meant to balance the excessive freedom of the magnates and to strengthen the authority of the king" (Ludwikowski 1991: 31). 
The essential difference between the American and the Polish constitutions consisted in their duration. The former has endured for more than two centuries; the latter only little more than a year. It is interested to observe how Ludwikowski comments on the short duration of the Polish constitution. We read in his book: "successful adoption of a constitution requires a mature constitution consciousness among those politically active in the nation. The readiness to fight for a constitution, to protect it and to observe its provisions, demands positive social sentiments and opinions about its usefulness" (Ludwikowski 1991: 34). This remark is much in accord with the remark made by the nineteenth-century British historian, Lord John Acton, who was very critical of Polish revolutionary upheavals in the nineteenth century. He claimed that freedom is the fruit of a mature civilization. Mature civilization takes time to develop, just like "a mature constitutional consciousness". Naturally a revolution, by its very nature, is a violent attempt to destroy the actual status quo without giving much promise for a more stable order that should follow.

The Polish constitution of May 3, just like the American Constitution, outlined only the main frames of the political structure, so that it could be adaptable to the changing conditions. Such a legal approach is called skeleton legislation, the contents of which are then filled in by detailed laws. This structure allows for further flexible interpretation.

The first Polish constitution sought to satisfy many expectations within and without the country. Inside the country it aspired "to satisfy the aspirations of the Polish burghers and the timid anticipations of the peasants without challenging that phobic, anti-revolutionary, and anti-democratic attitudes of the reactionary factions in neighboring, absolutist countries [...]" and "this combination of internal and external geopolitical factors, rather than the inherent qualities of the document, that settled the fate of the first Polish Constitution" (Ludwikowski 1991: 38). Ultimately, together with the Third Partition in 1795, the Polish State was eliminated. The 1791 Constitution fell, nevertheless it strengthened the spirit of the nation; it spoke about the rights and duties of the nobility; it approved of the primary function of Catholicism in Poland, but also conveyed some sense of religious tolerance.

From the fact that the State fell while the nation remained some might argue that it is a good proof that the State is of little importance or else that it is an unimportant addition to the nation. The situation in eighteenth- and nineteenth-century Poland indeed shows the durability of the nation despite the loss of the State, but it was never claimed as an example of the victory of the nation over the State. On the contrary, the Poles in the three partitioned segments had always sought to regain their State. There were some weak attempts to revive it (e.g. the Grand Duchy of Warsaw was installed by Napoleon in 1807). Ultimately the 1791 Constitution laid solid foundations for a possible State to come. 
Let us notice that usually ardent opponents of the State arrive at their radical opinions when they themselves are confronted with the abuse of the State's power in their day. Bastiat criticized revolutionary France, Nock and Hayek lived throughout the twentieth-century totalitarian regimes of national socialism and communism. Generally, they all saw clearly an essential difference between social action and State's action. Nock writes: "It is unfortunately none too well understood that, just as the State has no money of its own, so it has no power of its own. All the power it has is that society gives it, plus what it confiscates from time to time on one pretext or another; there is no other source from which State power can be drawn. Therefore every assumption of State power, whether by gift or seizure, leaves society with so much less power; there is never, nor can be any strengthening of State power without a corresponding and roughly equivalent depletion of social power" (Nock 1989: 3).

Witnessing the abuses of State power, people formulate very critical remarks addressed at the State and its very existence. Bastiat, for instance, calls the State "the great fictitious entity by which everyone seeks to live at the expense of everyone else" (Bastiat 1975: 144). Bastiat, as a realistic political commentator, is well aware of all the contradictory expectations from the State. Citizens often seek benefits from the State and at the same time expect that taxes will be very low. These two expectations cannot be satisfied.

Polish tragic history is a good proof that when the State usurps too much power, be it a self-confident monarch, wild gentry or greedy magnates, the result is always the same: attempts to take advantage of the situation on behalf of one's own position. Ultimately, the point is to enlarge the scope of power. Now I hope we can understand well the distrust of revolutionary solutions. At most they serve some groups not to improve the situation for the whole of society, but to seize power for one's own purposes. Nock outlines it clearly: the enlargement of State power means, by necessity, the decrease of society's power.

Nock claims that the main purpose of any State is victory and exploitation of the defeated, "the economic exploitation of a defeated group by a conquering group" (Nock 1989: 21). Pointing to Spencer, Nock makes a difference between government and the State. Government creates special conditions for society. Its purpose is social, it secures natural rights for the individual, whereas the State "is purely anti-social" (Nock 1989: 22). It is government that is meant by the Declaration of Independence. The State is anti-social because it is based on the persuasion that the individual has only those rights that are granted by the State. And this is how he assessed the rise of the State from the historical point of view. The State is always against society and in favour of its own aggrandizement, it "moves rapidly and with alacrity towards one that accrues to its own advantage; nor does it ever move towards social purposes on its own initiative, but only under heavy pressure, while its motion towards anti-social purposes is self-sprung" 
(Nock 1989: 23). The State accrues power, creates the mass-man (in terms of Ortega y Gasset). Because it is so easy to become powerful by means of the State all the classes eagerly use its mechanisms. Historically speaking, we had the nobility that possessed the State, it was a class-State, just like the merchant-State. In all these cases the State is anti-social and used for the narrow purposes of some classes. Since the State has this tendency for exploitation, likewise citizens tend to use it for their own exploitation. Lord Acton notes:

Power tends to corrupt and absolute power corrupts absolutely. Great men are almost always bad men, even when they exercise influence and not authority: still more when you superadd the tendency or the certainty of corruption by authority. There is no worse heresy than that the office sanctifies the holder of it. That is the point at which the negation of Catholicism and the negation of Liberalism meet and keep high festival, and the end learns to justify the means (Acton 1955: 335-336).

Primate Jan Pawel Woronicz stressed the pattern set by Sarmationism, the member of which is "a true defender of the democracy of the gentry, of political equality of all nobles, of limited royal and parliamentary powers, of principles of elected rather than hereditary monarchy, and the right of opposition" (Ludwikowski 1991: 54). Another political thinker, Henryk Rzewuski, praised legends and traditions, while he disdained written constitutions. He believed in national consciousness and national wisdom. Rzewuski firmly believed in social hierarchy. This natural hierarchy resides in aristocracy and nobility holding dominant position. Their political views today sound anachronistic. Rzewuski claimed that " $[\mathrm{t}]$ he decay of nations resulted from the fall of the nobility and the dissemination of democratic ideas, which undermined the belief in the moral superiority of noblemen and the trust that this social group fulfilled its commitments in accordance with noblesse oblige" (Ludwikowski 1991: 59). For him, the existence of the Polish nation was coequal with the existence of nobility. Nobility is identical with the national spirit, and anyone who is not filled with this spirit remains outside the Polish nation. The essence of the Polish spirt was to fight for freedom. Other nations have their own spirits: the German nation - truth, the English nation - utility. Indeed the first part of the nineteenth century in Britain is dominated by utilitarianism. The question is obviously open whether other nations do not crave for freedom. Rzewuski accepted the past of Poland together with its liberum veto.

Rzewuski's anachronism consisted basically in the fact that he sought to revive the golden freedom of old within Russian absolute empire (Ludwikowski 1991: 69). Obviously such a pattern for Polish conservatism could not be blindly followed. As we know, conservative itself is not against any change; consequently it does not stick to old values at any cost. One should show wisdom in selecting which values are worthy of imitation and which should be abandoned. 
In a totalitarian regime, where often people have to fight against their State (using various methods in accord with the rule that an end sanctifies the means), its citizens learn that opposing it is something positive or even heroic. Being against the State arises to virtue. Then, at the moment of regained independence, when the circumstances are entirely transformed, it is very difficult to unlearn bad practices one has acquired.

Nock formulates his critical remarks under concrete circumstances, namely, the presidency of Franklin Delano Roosevelt and his New Deal policy, which ultimately amounted to the overgrowth of the State. Therefore one can understand his pent-up negative emotions when he writes "that the State owes its citizens a living" (Nock 1989: 4).

Man is a contingent being and he has to make up for his contingency in collaboration with others, through the ups and downs of daily reality. When the State promises to release its citizens of their contingency, of all the ills it is only trying to accumulate power. Nock sees clearly a difference between the State power and social power, and he is certain that the latter is more effective than the former. According to Nock, it can also easily be shown that it is better to mobilize social power at the moment of crisis. Social power, once mobilized, brings about concrete effects, does not waste resources and leaves behind a very practical lesson: in the time of need people learn to rely on one another. If, however, social power is too readily replaced by State power, this causes its depletion. Then, when needed, it looks up to the State rather than to human resources. Social power must be practiced in order to develop into something persistent. The situation resembles that in from the world of bodily physiology, i.e. any organ that is not used undergoes atrophy?

Yet, even in Poland, despite the negative attitudes towards the State's abuses, the general tendency was to regain the State, not to do away with it. Another question is interesting: why is the increase of State power accompanied by the depletion of social power? Some people claim that this interdependence does exist ${ }^{8}$. Was German society weak prior to the outbreak of the Second World War? Our intuition seems to be to the contrary. Rather it was strong and alert, firmly united around the leader. Notwithstanding that intuition, we can still say that it was weak because it could not think for itself, it could not think independently, and entirely relied on the will of the ruler. This general alert of society is designed to prepare it for war, indeed for the purposes of the State, to transform it into a uniform and destructive mass. Metaphorically speaking, society becomes the State's iron fist ready to impart a deadly blow at all opponents (without and within the State). We

\footnotetext{
${ }^{7}$ See more about that in: J. Woodall (ed.), 1982, Policy and Politics in Contemporary Poland, passim.

${ }^{8}$ See more on this relationship between the state and society, especially in the period of economic transition from a state-run economy to the free market, J. Bell, 2001, The Political Economy of Reform in Post-Communist Poland, passim.
} 
find a similar line of thinking in the main representative of the Austrian School of Economics and an ardent opponent of excess State power, Ludwig von Mises, for whom the State can only be strong by the strength of society.

In a democratic regime, however, this depletion of social power is related to adopting a passive attitude, to looking up to the State for all kinds of assistance. In a democratic system, however, society starts to behave like a parasitic organism that saps up the Treasury; expectations are high and social groups look at one another with envy, as competitors to the same money.

\section{Conclusion}

Perhaps those who happen to baulk at the State's overactivity in the area of historical policy, in building monuments or holding celebrations are wrong. If they claim that the State should rather be more active in strengthening the economy, do not they thereby demand redistribution? From the point of view of the free market, for instance, would it not be more proper for the State to attendant to national identity rather than to organize the economy? In like manner the State can retain its modest prerogatives and remain committed to the construction of the intellectual, spiritual strongholds (frameworks) of the State. At the same time the State limits its activity to the level of some universal values that can be shared with society. The paradox of this situation is that citizens have great expectations from the State, but the moment it shows up they do not want to see its face, they yearn for a faceless State.

The example of the Polish State and the nation's struggle to regain it shows that the State is important. At the same time we have to agree with those who claim that no social group should gain domination over any other groups. The picture of the State is rightly interpreted through the activity of its government. We can repeat after Americans that government is by the people, for the people, and from the people.

\section{References}

Acton J.E, 1955, Essays on Freedom and Power, New York.

Bastiat F., 1975, The State, [in:] Selected Essays on Political Economy, trans. from the French by S. Cain (edited by G.B. de Huszar), Irvington-On-Hudson: The Foundation for Economic Education, Inc.: 140-151.

Bell J., 2001, The Political Economy of Reform in Post-Communist Poland, Cheltenham: Edward Elgar Publishing Limited.

Etzioni A., 1971, The Active Society. A Theory of Societal and Political Processes, The Free Press, New York. 
Kalyvas A., Katznelson I., 2008, Liberal Beginnings. Making a Republic for the Moderns, Cambridge University Press.

Krastev I., 2017, After Europe, University of Pennsylvania Press, Philadelphia.

Ludwikowski R.R., 1991, Continuity and Change in Poland. Conservatism in Polish Political Thought, The Catholic University of America Press, Washington, D.C.

Mises L. von, 1966, Human Action. A Treatise on Economics, Contemporary Books, Inc., Chicago.

Mises L. von, 1985, Omnipotent Government. The Rise of the Total State and Total War, Libertarian Press, Inc., Spring Mills.

Nock A.J., 1989, Our Enemy, the State, A Free Life Editions Book, New York.

Oppenheimer F., 1997, The State, trans. J. Gitterman, Fox \& Wilkes, San Francisco.

Ray J.L., 1990, Global Politics, Houghton Mifflin Company, Boston.

Rose W.J., 1944, The Rise of Polish Democracy, G. Bell \& Sons, LTD, London.

Rummel R.J., 1997, Power Kills. Democracy as a Method of Nonviolence, Translation Publishers, New Brunswick.

Spencer H., 1982, The Man versus the State. With Six Essays on Government, Society, and Freedom, Liberty Classics, Indianapolis.

Woodall J. (ed.), 1982, Policy and Politics in Contemporary Poland, Frances Pinter (Publishers), London.

\section{Państwo - konieczność albo wróg?}

Zarys treści: Artykuł przedstawia państwo z historycznego i analitycznego punktu widzenia. Jeśli chodzi o historię, mamy tu dwa rozwiązania. W tekście zostały określone jako rozwiązanie metafizyczne i kontraktowe. Rozwiązanie metafizyczne cechuje epokę przednowożytną. Tutaj punktem centralnym jest pogląd Arystotelesa, iż zasada społeczna zawarta jest w ludzkiej naturze. Na tej zasadzie zbudowane jest państwo. Podejście kontraktowe charakteryzuje epokę nowożytną - państwo powstaje jako efekt negocjacji. Historycznie rzecz ujmując, powstało wiele propozycji formy państwa: od przerośniętej instytucji do jej bardzo zubożonej formy. Autor proponuje skromne podejście do rozumienia państwa: jest potrzebne dla zdrowia społecznej wspólnoty. Jednakże warunkiem tego zdrowia jest państwo ograniczone, które pozostawia dużo przestrzeni dla rozwoju społeczeństwa i ważnych społecznych relacji.

Słowa kluczowe: historia, Hobbes, Locke, Ludwig von Mises, Nock, ograniczenie, państwo, Polska, Spencer.

Jan Kłos

John Paul II Catholic University of Lublin, Poland

Faculty of Philosophy

Department of Social and Political Ethics

e-mail: klosjan@kul.lublin.pl 